Asia Pacific Journal of Environmental Law, Vol. 22 No. 1, 2019, pp. 1-6

\title{
Editorial
}

\section{Forests, corruption, environmental degradation, protection of species and cooperation in the Asia Pacific region}

\section{APJEL IN THE ASIA PACIFIC REGION}

This is the first issue of APJEL for 2019, and it features articles covering issues of development and environmental law and governance in Australia, Australia and China, Bangladesh and China, Indonesia, Papua New Guinea, and the South China Sea region, as well as a 'jurisprudential' article relevant to the region.

The number and breadth of Asian Pacific jurisdictions that have attracted the attention of articles in APJEL over the past several years is good evidence that there is increasing scholarly interest in understanding, learning from and improving environmental law and policy in the region. This growing focus is vital, given the evident risks confronting the region, including human-made environmental catastrophes, water and energy crisis and weaknesses in national, regional and global governance. ${ }^{1}$ Our 2017 issue included articles on aspects of environmental law in Australia, China, India, Japan and South Korea as well as on general issues affecting environmental governance in the Asia Pacific region. Our two 2018 issues included articles on Australia, China, Fiji, India, Indonesia, Japan, Solomon Islands and Thailand.

Recent issues of APJEL continue the journal's endeavour to publish high quality research on a broad range of environmental law issues across the Asia Pacific, drawing lessons from comparisons and contrasts with and between countries facing similar realities, constraints and opportunities. At the same time, it is through in-depth analysis of specific environmental law developments in specific jurisdictions that true comparative understanding can be developed and enriched, and the articles in the present issue illustrate ways in which environmental protection can be enhanced by considering quite particular problems.

\section{THE ARTICLES IN THIS ISSUE}

\subsection{Articles}

While this issue of APJEL does not have a dedicated 'theme', half of the articles focus, at least in part, on forest- and forestry-related issues. Researchers interested in further research on these and related issues might be interested in the 2017 edited volume Protecting Forest and Marine Biodiversity: The Role of Law, published by Edward Elgar. ${ }^{2}$ As noted in many of the chapters in that work, although forests are

1. World Economic Forum, Regional Risks for Doing Business (World Economic Forum, 2018) 20, 22.

2. Ed Couzens, Alexander Paterson, Sophie Riley and Yanti Fristikawati (eds), Protecting Forest and Marine Biodiversity: The Role of Law (Edward Elgar Publishing, 2017). 
extremely important to humanity - providing numerous essential environmental goods and services - they are significantly threatened and under-regulated. ${ }^{3}$

According to the Australian government, illegal logging is 'a major global problem [with] the theft, laundering and trade of illegal timber happens across the world, in all types of forests'; with 'negative impacts on forest ecosystems, communities and economies' . ${ }^{4}$ Illegal logging, it is explained, 'has been linked to organised crime, civil wars, murder, corruption, species extinction [and] environmental destruction'.

Australia has introduced new laws aimed at prohibiting the import of illegally harvested forest products from around the world. The legislation was reviewed soon after adoption, and there was intense debate on the expected costs of compliance, but proposed amendments were finally disallowed and stricter enforcement actions announced. The thrust of the article ${ }^{6}$ by Beatriz Garcia and Jonathan Verschuuren is to identify compliance issues which might be problematic in Australia; and then to propose ways that might assist in solving these, with these suggestions being based on experiences in the European Union and the United States. The argument is made that law enforcement can be used to help to shape market behaviour and to reinforce compliance; and that a national legality assurance system, established within the supplier country, is an effective way to ensure legality verification, to alleviate the burden on individual businesses to prove legality, and to support regulated communities to comply with legal requirements.

Australia is a developed country with a relatively sophisticated raft of environmental laws, and - more importantly - the infrastructure to be able to enforce these. This is not a situation enjoyed by every country for which illegal forestry activity is an important issue.

It is argued in the article ${ }^{7}$ by Shawkat Alam, Tuti Herawati, Herman Hidayat and Stephen Wyatt that many of the advantages enjoyed by developed countries - such as political stability and highly regulated systems of land tenure and ownership - are elusive within developing countries, where state intervention in the field of forest governance meets with resistance and faces significant hurdles. Recognising the challenges facing implementation of Indonesia's current systems of certification, and the failure thus far of government efforts to stem illegal forestry activity, this article examines the influence of certification on sustainable forest management (SFM) in Indonesia. The question of how certification requirements interact with both the domestic regulatory framework and expectations for community participation and engagement is particularly considered. The article reviews Indonesian efforts to implement SFM, as well as the basis of certification systems, before examining Indonesian experience with forest certification and then considering complementarity in government, private and community initiatives in SFM and how regulatory reform in support of a more participatory approach could contribute to achieving these goals. It is argued that the development

3. Ed Couzens, Alexander Paterson and Sophie Riley, 'Legal aspects of the protection of forest and marine biodiversity: understanding the context' in Couzens, Paterson, Riley and Fristikawati (n 2) 3-24, at 5-7, 14-17, 20-21 and 23-24.

4. Department of Agriculture and Water Resources, 'Illegal Logging' (Rev 16 January 2019) www.agriculture.gov.au/forestry/policies/illegal-logging.

5. Ibid.

6. 'Complying with Australia's illegal logging laws: tough reality after a soft start? Lessons from the United States and the European Union'.

7. 'Forest certification, state regulation and community empowerment: complementarity in seeking a viable solution to forest degradation in Indonesia?'. 
of the Indonesian voluntary forestry certification process shows that both certification schemes and government regulation have advantages and disadvantages for improving sustainable forest management. Increasing roles for communities, small-scale producers and traditional forest users would potentially provide additional options for, and enhance capacity for, sustainable forest management.

One of the biggest problems faced in improving the conservation and ethical management of forests in the Asia Pacific region, particular in poorer developing countries, is the corrosive impact of corruption. This is a significant challenge, given the ongoing reconfiguration in North-South relations, and international community moves to implement the Sustainable Development Goals, which present new opportunities for corruption (even as the Sustainable Development Goals call for a reduction in corruption and bribery in all their forms). ${ }^{8}$

The issues of corruption and environmental degradation should arguably be seen as interrelated. In Papua New Guinea (PNG), the relationship between corruption and the environment can be seen in the continuing corruption that exists in the country's forestry industry. In her article, ${ }^{9}$ Hannah Harris focuses on key actors, values and interests across geographic and institutional spheres which all contribute to providing corrupt incentives within PNG. The PNG government, foreign corporations, customary land owners, NGOs, multilateral organisations, even foreign governments and consumers, all play roles in the PNG context. Harris argues that these actors and their motives must be understood and harnessed in order to reduce corruption and to improve environmental outcomes in PNG. To balance power dynamics and diverse incentives amongst these actors requires the use of multiple legal and political tools as components of the solutions needed, including: political pressure, international law, domestic legislation, aid and technical assistance, education and enforcement of existing legal frameworks. The concept of an experimentalist governance framework for environmental protection is valuable in this context, due to its fluidity, responsiveness and adaptability in complex environments with multiple stakeholders.

As important as individual people are, it is important also to understand that the powerful corporation - seen as an entity which takes on a life of its own, beyond the people which comprise it - is an environmental actor within its own right.

In their article, ${ }^{10}$ Wim Huisman and Daniel Sidoli consider cases in which corporations are accused of contributing to human rights abuses, environmental degradation and corruption in developing nations. The article assesses relationships between these three harms from the perspective of corporations as actors involved in producing those harms. Based on a cross-case analysis of 45 cases in which this nexus of harms is found, the article assesses the atrocity crimes/environmental degradation/corruption-nexus, by studying agency (crime scripts), actors (industries and corporations) and connections

8. See, for example, SDG 16: 'Promote peaceful and inclusive societies for sustainable development, provide access to justice for all and build effective, accountable and inclusive institutions at all levels', https://sustainabledevelopment.un.org/sdg16.

9. 'Corruption and the forestry industry in Papua New Guinea: transnational actors, local dynamics and environmental impact'. This article emanated from the 6th Ingram Colloquium on 'The Environmental Degradation-Corruption Nexus: Improving Environmental Governance in Developing Countries' Corruption Issues, held at the UNSW Sydney, 2-3 November 2017. The Ingram Colloquium is named after Mr James Ingram AO, former Australian diplomat and former Executive Director of the United Nations World Food Program.

10. 'Corporations, human rights and the environmental degradation-corruption nexus'. This article emanated also from the 6th Ingram Colloquium, 2017, ibid. 
(how are the three harms related?) in these cases. The analysis shows that corporations are mostly indirectly involved in atrocity crimes, but directly involved in environmental harm and corruption. Extractive industries are overrepresented and the many entanglements with state agents qualify as state-corporate crime. In conclusion, relations between the different harms are considered.

Moving smoothly from an assessment of forests and forestry, illegality and the role of corporations, it is important to see the best approach to tackling challenges in sectors such as these as one which addresses not only corporations but also the powerful banking sector. The relationships between corporations and banks will perforce be symbiotic, mutually reinforcing and inextricable and both will benefit from legislative and policy frameworks conducive to ethical environmental practices.

Sherin Kunhibava, Sarah Tan Yen Ling, Nur Faizira Abdul Rahman and Md Khalil Ruslan argue in their article ${ }^{11}$ that green banking frameworks encourage banks to manage their in-house operations and lend and invest in an environmentally sustainable manner. The authors explain that there are at present six nations in Asia that have green banking frameworks - these being Bangladesh, Cambodia, China, Indonesia, Mongolia and Vietnam. Each of the six countries have distinctive green banking policies and frameworks suited to their own national agendas. This article provides a summary of the main green banking frameworks issued by each country's respective regulatory authority or banking association; and then considers possible reasons why these six countries have established such frameworks. There is then a more detailed focus on the green framework and banking policies, and on the effects of introducing such frameworks and policies, practised in Bangladesh and China, given their experience and strong establishments. The article concludes with recommendations on what more might be done to enhance green banking in Bangladesh and China - and, by implication, in other countries.

While legislative guidance toward ethical practices within corporate functioning is obviously crucial if there is to be sustainable development, it can be argued that our environmental problems are so severe that what is really needed is in fact a fundamental revisiting of our relationship with nature.

In her article, ${ }^{12}$ Sophie Riley argues that land management practices reconstruct nature by destroying and degrading habitats, species and ecosystems, and creating environmental imbalance. The latter can manifest in over-abundant or invasive species, imposing a welfare burden on unwanted animals when they are targeted for eradication and control. Such approaches not only overlook animal well-being, but ignore the role that humans have played in species' classifications. As societies grapple to manage the environments in which they have created instability, they have also started to realise that standards set by paradigms such as sustainable development do not sufficiently engage with the efficacy or ethics of existing practices. The argument is put forward that a synthesis of law and science, drawn respectively from emerging paradigms, such as the Great Law of Earth jurisprudence and principles of compassionate conservation, can help to guide environmental regimes towards more effective and ethical outcomes. From a legal perspective, the Great Law subordinates human law to a metaphorical nature's voice, while from a scientific perspective, the scientific underpinnings of compassionate conservation identify that voice. Although compassionate conservation injects

11. 'Green banking frameworks in Asia with an in-depth focus on Bangladesh and China'.

12. 'Listening to nature's voice: invasive species, Earth jurisprudence and compassionate conservation'. 
empathy into the decision-making processes, it is a form of empathy based on science that commences from the stipulation that regulators should first do no harm. It is a call that is specifically relevant to invasive species, where current regulation is based on harming certain species, whilst simultaneously overlooking environmental threats generated by humans. By using science to identify nature's voice, and employing law as a means to listen to that voice, regulators could design regimes that work with nature, rather than trying to reconstruct and dominate it.

A clear theme which emerges from all of the articles in this issue is that legislation can take us only to a certain point - beyond that, what is needed is the fostering of, facilitation of and ongoing support for cooperation. ${ }^{13}$ This must occur between people, between people and law-makers and managers, between people living in different countries, and between those countries themselves. One of the most obvious, but most often ignored, links between countries, and between people within countries, is in the field of migratory species.

Evan Hamman explains in his article ${ }^{14}$ that, every year, millions of migratory birds journey along the East Asian-Australasian Flyway (EAAF). The scope of the EAAF encompasses Asia Pacific nations like Australia, New Zealand, China, Japan, South Korea, Vietnam, Malaysia and Indonesia. The effective conservation of these birds rests upon the implementation of bilateral legal agreements, as well as upon non-binding regional initiatives along this North-South nexus. This article evaluates the implementation of one of the most important bilateral bird agreements in the region - the China-Australia Migratory Bird Agreement, 1986 (CAMBA). The main obligations in CAMBA are identified; as are the legal initiatives adopted by both China and Australia which reflect CAMBA's obligations. Whilst Australian law makes specific reference to CAMBA, Chinese law is far less direct, though perhaps no less effective. The argument is made that the findings in this article have relevance for an improved understanding of the mechanisms for transboundary governance of migratory birdlife, especially in the Asia Pacific.

Sometimes, unfortunately, political and economic tensions between countries might be so great that cooperation in the form of the adoption of direct treaties might be impossible. Yet, the need for cooperation remains if the environment is not to be degraded beyond recovery.

Amber Rose Maggio, in her article, ${ }^{15}$ explores current trends in regional cooperation in the politically troubled South China Sea with regard to marine environmental protection. While there are a large number of bodies engaged in some way in issues relating to the marine environment, this region faces some serious challenges in cooperative efforts. The article gives an overview of the current cooperation landscape, highlights the most serious challenges faced and considers the way forward. The possibility of the appropriateness of issue-based solutions, particularly to the management of marine litter, is examined, while at the same time emphasis is laid on the importance of the implementation of international obligations and standards.

13. Cameron Holley, Neil Gunningham and Clifford Shearing, The New Environmental Governance (Earthscan, 2012).

14. 'Bilateral agreements for the protection of migratory birdlife: The implementation of the China-Australia Migratory Bird Agreement (CAMBA)'.

15. 'Regional cooperation for protection of the marine environment in Southeast Asia: Current trends in the South China Sea'. 


\subsection{Book reviews}

Finally in this issue, there are two book reviews. Book reviews make a significant contribution to scholarship, alerting readers to potentially valuable resources.

The first review is by Michael Addaney, reviewing Benoit Mayer's book The International Law on Climate Change. ${ }^{16}$ Addaney describes the book as providing 'what could be the first comprehensive textbook of the emerging field of international climate change law as a discipline'. The review concludes that the book 'provides a constructive outline of the international law on climate change but, by so doing, also reveals the political and legal challenges of this emerging area of international law especially its limited ability to deliver binding obligations to guide international responses to climate change'.

The second review, by Gayathri Naik, is of Gabriel Eckstein's book The International Law of Transboundary Groundwater Resources. ${ }^{17}$ Naik argues that Eckstein's book 'attempts to provide a detailed analysis of the existing legal framework with the help of scientific explanations of groundwater and aquifer hydrogeology'. Further, many past agreements relevant to water, and even many in action now, 'are based on limited knowledge of subsurface water resources and their characteristics'; and 'increasing water demand and the alarming levels of exploitation of groundwater at an alarming level remind us of the need for sustainable management and conservation of this resource to ensure both intra- and inter-generational equity and sustainable development, the fulfilment of which requires scientific understanding of the resource characteristics'.

\section{COMMENT}

APJEL continues to reflect exciting developments in environmental law in the Asia Pacific region and the eight articles published in the first issue of Volume 22 (2019) do, we hope, meet our goal of reflecting the breadth of environmental law developments in the region. As always, we look forward to further submissions which contribute toward understanding both regional dynamics and particular country experiences.

The editorial team would like also to take this opportunity to thank the anonymous reviewers on whose time we have imposed, and on whose expertise we have drawn, to assess the articles in this and previous issues. While we cannot thank them in print by name, we would like to acknowledge that their input has strengthened significantly the scholarship contained in this volume, and we are deeply grateful.

Ed Couzens and Tim Stephens Editors

Assisted on this issue by Saiful Karim

Faculty of Law, Queensland University of Technology, Australia Cameron Holley

Faculty of Law, University of New South Wales, Australia Kate Owens

The University of Sydney Law School, Australia

16. Cambridge University Press, 2018, 302 pp.

17. Earthscan/Routledge, 2017, 187 pp. 